\title{
Determination of Titanium, Zirconium, Niobium, and Tantalum in Steels: Separations by Anion-Exchange
}

\author{
John L. Hague and Lawrence A. Machlan
}

\begin{abstract}
A procedure is described for the determination of titanium, zirconium, niobium, and tantalum in steel. These elements are concentrated by selective precipitation with cupferron from a hydrochloric acid solution of the sample, and then ignited to the oxides. The oxides are fused, and dissolved in a hydrochloric-hydrofluoric acid mixture. Three separate eluates, containing titanium and zirconium, niobium, and tantalum, result from elution with mixtures containing ammonium chloride, hydrochloric acid, and hydrofluoric acid from a column of Dowex-1 anion-exchange resin. Boric acid is added to the eluates to complex the hydrofluoric acid, and the elements are precipitated with cupferron. Titanium is determined by the hydrogen-peroxide method, and zirconium by the phosphate-gravimetric method. Niobium and tantalum are determined by the hydroquinone- and pyrogallolphotometric methods, or by weighing the oxides.
\end{abstract}

\section{Introduction}

The increased use in recent vears of elements that form complexes with carbon and nitrogen in metallurgical alloys has presented some interesting problems to the analytical chemist. For example, the high-temperature and heat-resisting alloys used in rockets and jet engines contain various combinations of tungsten, molybdenum, titanium, zirconium, niobium, tantalum, and aluminum in addition to the major elements, nickel, cobalt, iron, and chromium. Even the usual grades of stabilized stainless steels are becoming complex allovs through the use of scrap in melting charges. Because of the complexity of these materials, spectrographic and X-ray methods are desirable for production control and acceptance testing. Adequate chemical procedures for the analysis of standards used in calibrating these instruments are especially needed.

The difficulties encountered in handling combinations of zirconium, titanium, niobium, and tantalum are well known $[10,19] .{ }^{1}$ During the last few years it has been shown $[1,20]$ that combinations of titanium, niobium, and tantalum can be separated by selective elution from cellulose columns with methyl ethyl ketone in combination with hydrofluoric and hydrochloric acids or their ammonium salts. Several papers $[2,6,14,15,16]$ have shown that useful separations in this group of elements can be made on anion-exchange resin columns, using mixtures of hydrochloric and hydrofluoric acids as elution reagents.

The method described here provides for the determination of titanium, zirconium, niobium, and tantalum in the range of a few thousandths of one percent to approximately one-half percent in steels. The procedure involves most of the separations required in determining larger percentages of these elements and illustrates the application of the ionexchange technique to otherwise very difficult separations. Direct photometric methods for the determination of molybdenum [10, p. 315] and tungsten [18] in steels are available for this concentration range, and these elements are not considered except as they affect other determinations.

Figures in brackets indicate the literature references at the end of this paper.
A concentration of titanium, zirconinum, niobium, and tantalum is effected by cupferron precipitation $[4,5]$ with most of the iron present in the reduced condition. The small amount of iron coprecipitated serves as a gathering agent. Most of the chromium, nickel, cobalt, manganese, and iron pass into the filtrate, so that a satisfactory concentration can often be made from a sample as large as $25 \mathrm{~g}$.

The cupferron precipitate is ignited to the oxide, leached with hydrochloric acid, and filtered. The filtrate is evaporated nearly to dryness. The insoluble material is ignited, treated with sulfuric and hydrofluoric acids to eliminate silica, and fused in sodium pyrosulfate. A mixture containing 50 percent by volume of hydrochloric acid and 10 percent by volume of hydrofluoric acid is added to the evaporated filtrate, and the melt is dissolved in the resulting solution.

The solution is transferred to an anion-exchange column, and the titanium and zirconium are eluted with a 50-percent hydrochloric 10-percent hydrofluoric acid solution. A second fraction containing molybdenum, tin, and iron is eluted with a mixture containing 12.5 percent by volume of hydrochloric acid, 20 percent by volume of hydrofluoric acid and 7.2 percent by weight of ammonium chloride, and discarded. Niobium is collected in a third fraction by elution with an ammonium chloride-hydrofluoric acid solution. Tantalum is collected in a fourth fraction by elution with an ammonium chlorideammonium fluoride solution adjusted to a $p \mathrm{H}$ of 5 to 6.

The first fraction containing the titanium and zirconium (and in addition, such elements as chromium, nickel, tungsten, and vanadium) is mixed with a boric acid solution to complex the hydrofluoric acid. A small amount of iron is added as a gatherer, and a precipitation is made with cupferron. The precipitate is ignited, fused in pyrosulfate and dissolved in hydrochloric acid. A sodium hydroxide precipitation $[10$, p. 579] is made to eliminate vanadium and tungsten, and the precipitate is ignited. The oxide mixture is fused in pyrosulfate and dissolved in diluted sulfuric acid. Titanium is determined in a suitable aliquot by a differential photometric measurement of the colored complex formed 
with bydrogen peroxide [10, p. 581]. The solutions used for the photometric determination of titanium are combined, and zirconium is determined by the phosphate method [10, p. 569].

The third fraction containing the niobium is treated with boric acid to complex the hydrofluoric acid, and zirconium, low in niobium and titanium, is added as a coprecipitant. After precipitation with cupferron, the ignited oxide is fused in pyrosulfate and dissolved in ammonium oxalate solution. A suitable aliquot of the solution is evaporated to fumes with sulfuric and nitric acids to destroy the oxalate ion. The niobium is determined photometrically with hydroquinone [11, 12] in concentrated sulfuric acid. Larger amounts of niobium, such as are encountered in type 347 stainless steel, can be precipitated with cupferron after the addition of boric acid, ignited to the oxide, and weighed.

Tantalum in the fourth fraction is recovered from the eluate by precipitation with cupferron after the addition of boric acid and zirconium. The ignited oxide is fused in pyrosulfate and dissolved in ammonium oxalate-ammonium citrate solution. The photometric determination of tantalum employs the color reaction with pyrogallol [10, p. 610]. Larger amounts of tantalum can be precipitated with cupferron after the addition of boric acid, ignited to the oxide and weighed.

The present procedure is somewhat long, as two days are required to carry out the ion-exchange separations, unless the columns are operated continuously, and several days are required to finish the various determinations. The method does, however, compare favorably in time and ease of operation with the other chemical methods available for this combination of elements, and lends itself readily to handling a number of samples at the same time if enough columns are prepared.

\section{Apparatus and Resins}

Ion-Exchange Columns. The columns are constructed of polystyrene and are approximately 12 in. long and of 1 in. inside diameter. A simple column can be prepared from a 12-in. length of polystyrene tubing as follows: The bottom of the tube is closed by a waxed No. 5 rubber stopper with a $3 / 16$-in. hole. A 6-in. length of polystyrene tubing, $3 / 16$ in. outside diameter, 116 -in. bore, is inserted into the hole flush with the upper surface of the stopper. Another 6 -in. length of this tubing is attached to the smaller tube with a 2 -in. length of Tygon R tubing, and the flow controlled by a hosecock clamp on the Tygon tubing. However, if a number of analyses are to be made, it is convenient to arrange the columns so that a number can be operated with a minimum of attention, as has been done previously with glass columns [7]. Plastic columns suitable for such an assembly have been developed [13]. The columns used in this work were obtained and assembled as illustrated in figure 1.

These columns are equipped with machined "Doletype" fittings of polystyrene. Inlet and outlet tubes are of polyethylene; flexible connections where necessary are made of Tygon $\mathrm{R}$ tubing. The flow of solutions is controlled by hosecock clamps on the flexible connections. The connections should be carefully done and checked to avoid any possibility of leakage of the solutions containing hydrofluoric acid.

Resins. Dowex-1, 200- to 400-mesh, 8- to 10percent divinylbenzene cross linkage are used. Experience over a period of several years has shown that the mesh size of these resins may vary considerably from lot to lot. In order to avoid difficulty, the resins as received are air dried, and sieved through a 270-mesh sieve. Material retained on the 270mesh sieve is used for other purposes. Most of the fines are removed from the fraction passing the 270mesh sieve as follows: Prepare a suspension of the resin in diluted hydrochloric acid $(1+19)$. This terminology denotes 1 volume of concentrated hydrochloric acid, sp gr 1.18, diluted with 19 volumes of water. If no dilution is specified, the concentrated analytical reagent is meant. The coarser fraction is allowed to settle 10 to $15 \mathrm{~min}$, and the fines removed by decantation. Repeat the process several times until most of the very fine material has been removed from the suspension.

Cover the bottom of the ion-exchange column with a layer of acid-resistant vinyl-chloride plastic wool, $1 / 4-$ to $3 / 8$-in. thick. Add portions of the resin suspension to obtain a settled column of the resin 6 to 7 in. high. The loaded column should be run through several cycles of elution with alternate additions of diluted hydrochloric acid $(3+1)$ and diluted hydrochloric acid $(1+9)$ to remove the remainder of the fines. The column is then washed with diluted hydrochloric acid $(1+3)$ and is ready for use. Resin columns prepared in this way have been used for several years. The only maintenance required is to empty and refill the column with the resin charge if the flow rate becomes excessively slow due to packing. The resin charge should not be allowed to become dry.

Polyethylene Ware. 250-ml and 600-ml Griffinform beakers are required. The high-temperature polyethylene ware is useful for evaporations at steam-bath temperatures. Bottles are used for preparing and dispensing acid mixtures containing hydrofluoric acid.

Colorimeter. An Evelyn type of colorimeter, including filters, voltage stabilizer, and galvanometer, was used for the measurements reported. Matched test tubes (22 by $175 \mathrm{~mm}$ ) were used as absorption cells.

\section{Procedures and Discussion}

\subsection{Preparation of the Solution for Ion-Exchange Separations}

Reagents

Cupferron Solution (60 g/liter). Dissolve $6 \mathrm{~g}$ of cupferron in $90 \mathrm{ml}$ of water, dilute to $100 \mathrm{ml}$, and filter through a dry filter. This solution should be prepared as needed and cooled $\left(5^{\circ} \mathrm{C}\right)$, as the solution is not stable. 

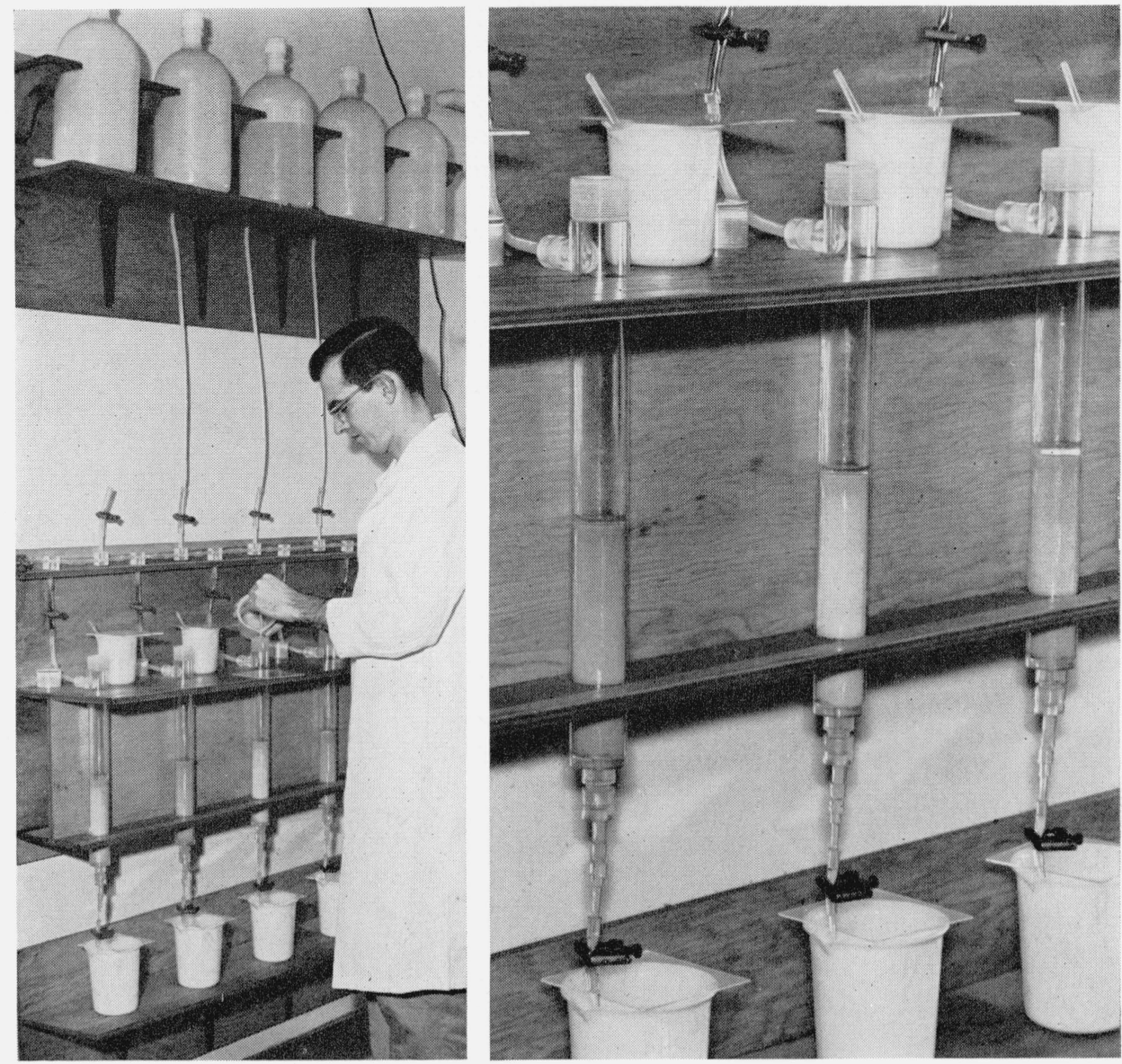

Figure 1. Assembly (left) and close-up view (right) of ion-exchange columns.

Cupferron Wash Solution. Add $25 \mathrm{ml}$ of cupferron solution to $975 \mathrm{ml}$ of cold $\left(5^{\circ} \mathrm{C}\right)$ diluted hydrochloric acid $(1+9)$. Prepare as needed.

Procedure

Transfer 5 to $25 \mathrm{~g}$ of the sample to a covered 600 or $800-\mathrm{ml}$ beaker, and add 225 to $450 \mathrm{ml}$ of diluted hydrochloric acid $(1+2)$. Warm the solution on a steam bath, or if necessary over a burner, until the sample dissolves. Adjust the volume of the solution with water to 400 to $500 \mathrm{ml}$, so that the solution contains approximately 15 percent by volume of hydrochloric acid. (One gram of iron requires approximately $3 \mathrm{ml}$ of hydrochloric acid for solution.)

Cool the solution to $5^{\circ} \mathrm{C}$, and add cupferron solution dropwise and with continuous stirring until the iron starts to precipitate. The precipitate will begin to coagulate when precipitation of titanium, zirconium, niobium, tantalum, vanadium, etc., is complete. Add several milliliters of cupferron in excess (approximately 25 to $30 \mathrm{ml}$ in total), which will cause the precipitate to assume a reddish color. The precipitated iron will act as a "gatherer" for the other elements. Add a ball of paper pulp equivalent to about one-half of an 11-cm filter paper, stir until the pulp is well dispersed, and allow the precipitate to settle. Filter through a double 7 -cm close-texture filter paper fitted to a Büchner funnel and precoated with some filter pulp. Transfer the precipitate to the funnel and wash well, using $400 \mathrm{ml}$ of cupferron wash solution. Transfer the precipitate and papers to a $30-\mathrm{ml}$ porcelain crucible, and carefully ignite at a low temperature $\left(500^{\circ}\right.$ to $\left.550^{\circ} \mathrm{C}\right)$ until carbon is removed.

Transfer most of the ignited oxides to a $250-\mathrm{ml}$ beaker, and dissolve the remainder in the crucible in warm diluted hydrochloric acid $(1+1)$. Finally police and wash the crucible, with the same acid, transferring the washings to the $250-\mathrm{ml}$ beaker. Adjust the volume to about 30 to $35 \mathrm{ml}$ with diluted hydrochoric acid $(1+1)$, and digest on the steam bath for several hours. Add paper pulp, and filter the warm solution through a 9-cm close-texture paper containing pulp, catching the filtrate in a 250-ml high-temperature polyethylene beaker. Transfer the undissolved residue to the paper and wash with diluted hydrochloric acid $(1+1)$. Evaporate the filtrate and washings to a volume of approximately 5-ml, and reserve. Transfer the precipitate and paper to a $25-\mathrm{ml}$ platinum crucible, and ignite at a low temperature.

Add $1 \mathrm{ml}$ of sulfuric acid and 10 to $15 \mathrm{ml}$ of hydrofluoric acid to the crucible, and remove the hydro- 
fluoric and sulfuric acids by heating on an air or sand bath, being careful that the sulfuric acid does not creep over the top of the crucible. Finally ignite at a low temperature, and fuse the oxides with $1 \mathrm{~g}$ of sodium pyrosulfate.

Add $30 \mathrm{ml}$ of a hydrochloric-hydrofluoric acid mixture, containing 50 percent by volume of hydrochloric acid and 10 percent by volume of hydrofluoric acid, to the polyethylene beaker. Transfer the crucible and melt to the beaker, and warm on a steam bath. Manipulate the crucible with a polyethylene stirring rod until the melt dissolves, remove the crucible with the rod or platinum-tipped tongs, and wash well with the 50-percent hydrochloric10-percent hydrofluoric acid solution. The solution. should be clear for the separations which follow to succeed, and the volume should be approximately 50 to $75 \mathrm{ml}$.

If large quantities (25 $\mathrm{mg}$ or more) of titanium or zirconium are present, the amount of flux and the volume may have to be increased to obtain a clear solution. Alternatively, the solution may be filtered through a close-texture paper onto the column, and the paper washed thoroughly with the hydrochlorichydrofluoric acid solution to dissolve any insoluble material.

The fusion is made with sodium pyrosulfate because the potassium salt forms insoluble fluoroborates in the procedure described in section 3.3.a. If titanium and zirconium determinations are not desired the fusion may be made with potassium pyrosulfate, provided the tantalum does not exceed $50 \mathrm{mg}$ or so; otherwise sparingly soluble potassium fluorotantalate will precipitate. Such solubility considerations do not arise with mixtures of hydrous oxides or metals, which can be dissolved directly in the mixed acids.

\subsection{Ion-Exchange Separation of Titanium and} Zirconium (+Hafnium), Niobium, and Tantalum

\section{Reagents}

Hydrochloric-Hydrofluoric Acid Solution. Add 500 $\mathrm{ml}$ of hydrochloric acid to $300 \mathrm{ml}$ of water, add 100 $\mathrm{ml}$ of hydrofluoric acid, dilute to 1 liter with water, and mix well. The solution is referred to as 50-10 mixture in the procedure.

Ammonium Chloride Solution (240 g/liter). Dissolve $240 \mathrm{~g}$ of ammonium chloride in $800 \mathrm{ml}$ of water by warming, and dilute to 1 liter with water. Filter to remove insoluble material. This solution is used as a stock solution in preparing the three solutions which follow.

Ammonium Chloride-Hydrochloric-Hydrofluoric Acid Solution. Transfer $300 \mathrm{ml}$ of ammonium chloride solution, $200 \mathrm{ml}$ of hydrofluoric acid and 125 $\mathrm{ml}$ of hydrochloric acid to a polyethylene bottle. Dilute to 1 liter with water, and mix well. This solution is referred to as 7-12 1/2-20 mixture in the procedure.

Ammonium Chloride-Hydrofluoric Acid Solution. Transfer $600 \mathrm{ml}$ of ammonium chloride solution and $40 \mathrm{ml}$ of hydrofluoric acid to a polyethylene bottle, dilute to 1 liter with water, and mix well. This solution is referred to as 14-4 acid mixture in the procedure.

Ammonium Chloride-Ammonium Fluoride Solution. Transfer $600 \mathrm{ml}$ of ammonium chloride solution and $40 \mathrm{ml}$ of hydrofluoric acid to a polyethylene beaker. Adjust the solution to a $p \mathrm{H}$ of 5 to 6 with ammonium hydroxide (approximately 80 to $85 \mathrm{ml}$ will be required), and dilute to 1 liter with water. This solution must be prepared with reasonable care, as a solution which is too acid will not completely elute the tantalum in the volume specified in the procedure. A solution which is too alkaline will precipitate tantalum in the column, spoiling the determination and the one which follows. This solution is referred to as 14-4 neutral mixture in the procedure.

\section{Procedure}

Transfer $50 \mathrm{ml}$ of the 50-10 mixture to the column in small increments (5 to $10 \mathrm{ml}$ ), and drain the acid to $1 \mathrm{~cm}$ above the resin bed. Discard the eluate. Transfer the solution, prepared according to the directions in the previous section, in small increments $(5$ to $10 \mathrm{ml})$ to the column with the bottom hose-cock clamp open. Add the sample as the solution moves down the column until all the sample has been transferred. Wash the beaker 4 to 5 times with $5-\mathrm{ml}$ portions of the 50-10 mixture, and finally wash down the sides of the column several times with the same mixture. Discard the first 20 or $25 \mathrm{ml}$ of solution from the column, and collect the remainder of the first fraction, containing the titanium and zirconium (+hafnium) along with vanadium, tungsten, chromium, etc., in a $600-\mathrm{ml}$ polyethylene beaker. Add a total of $350 \mathrm{ml}$ of the 50-10 mixture, this volume to include the washings and the solution used to elute the fraction. The hose-cock clamp should be adjusted so that the flow of the solution is approximately 100 to $125 \mathrm{ml} / \mathrm{hr}$. Allow the solution to drain to the top of the resin, and wash down the sides of the column with six or seven $5-\mathrm{ml}$ portions (a total of about $35 \mathrm{ml}$ ) of the $7-12 \frac{1}{2}-20$ mixture, allowing the solution to drain to the top of the column each time. Reserve the beaker containing the first eluate, and replace it with another $600-\mathrm{ml}$ polyethylene beaker.

Add a total of $350 \mathrm{ml}$ of the $7-12 \quad \frac{1}{2}-20$ mixture at a flow-rate of approximately 100 to $125 \mathrm{ml}$ per hour, and allow the solution to drain to the top of the column. Wash the sides of the column with six or seven 5-ml portions of the 14-4 acid solution, remove the beaker containing the second fraction, and replace with another $600-\mathrm{ml}$ polyethylene beaker. The second fraction contains primarily iron, and molybdenum and tin if present, and can be discarded.

Add a total of $300 \mathrm{ml}$ of the 14-4 acid mixture, maintaining the technique and flow-rate described in the previous paragraph. Wash the sides of the column with approximately 25 to $30 \mathrm{ml}$ of the 14-4 neutral mixture, remove the beaker containing the third fraction (niobium) and reserve. Replace the beaker with a 600-ml polyethylene beaker.

Elute the fourth and final fraction by the addition of a total of $300 \mathrm{ml}$ of the 14-4 neutral mixture, and reserve the solution for the determination of tanta- 
lum. The column is cleaned by the addition, in increments, of $50 \mathrm{ml}$ of diluted hydrochloric acid $(1+3)$, after which it is ready for the next sample.

It should be mentioned that painful burns can result from careless handling of hydrofluoric acid solutions. Any spills should be promptly washed up, and borax, or similar proprietary compounds, should be used several times a day in washing the hands or any skin area exposed to hydrofluoric acid.

\subsection{Determination of Titanium, Zirconium ( + Haf- nium), Niobium, and Tantalum}

\section{a. Titanium}

\section{Reagents}

Ferric Sulfate Solution (50 g/liter). Dissolve $5 \mathrm{~g}$ of hydrated ferric sulfate (low in titanium and zirconium) in $90 \mathrm{ml}$ of diluted sulfuric acid $(1+9)$, and dilute to $100 \mathrm{ml}$ with diluted sulfuric acid $(1+9)$.

Sodium Hydroxide Solution (100 g/liter). Dissolve $10 \mathrm{~g}$ of sodium hydroxide in $80 \mathrm{ml}$ of water, and dilute to $100 \mathrm{ml}$.

Ammonium Nitrate Wash Solution (20 g/liter). Dissolve $10 \mathrm{~g}$ of ammonium nitrate in $400 \mathrm{ml}$ of water, and dilute to $500 \mathrm{ml}$.

Standard Titanium Sulfate Solution (1 ml $=0.25$ $m g$ of titanium). Transfer $0.4170 \mathrm{~g}$ of titanium dioxide (a suitable portion of NBS Standard Sample 154 a may be used) to a $250-\mathrm{ml}$ Erlenmeyer flask, add $10 \mathrm{~g}$ of ammonium sulfate and $25 \mathrm{ml}$ of sulfuric acid, insert a short-stemmed glass funnel in the neck of the flask and heat cautiously to incipient boiling while rotating the flask over a free flame. Continue the heating until complete solution has been effected and no unattacked material remains on the wall of the flask. Cool and rapidly pour the solution into $450 \mathrm{ml}$ of cool water which is vigorously stirred. Rinse the flask with diluted sulfuric acid $(5+95)$. Transfer the solution to a $1,000-\mathrm{ml}$ volumetric flask, dilute to the mark with diluted sulfuric acid $(5+95)$, and mix thoroughly.

\section{Procedure}

Transfer $40 \mathrm{~g}$ of boric acid to a 1,500-ml beaker, add $700 \mathrm{ml}$ of water, and warm to dissolve the acid. Add the first fraction of solution containing the titanium and zirconium to the warm boric acid solution with continuous stirring, and add by pipet $2 \mathrm{ml}$ of the ferric sulfate solution. Cool to $5^{\circ} \mathrm{C}$, and add 25 to $30 \mathrm{ml}$ of cupferron solution slowly while stirring. Add paper pulp, stir the solution well to distribute the pulp, and allow the precipitate to settle for 10 to $15 \mathrm{~min}$. Filter through a double thickness of close-texture filter paper fitted to a $7-\mathrm{cm}$ Büchner funnel and precoated with a little filter pulp. Transfer the precipitate to the funnel, and wash well with $400 \mathrm{ml}$ of cold $\left(5^{\circ} \mathrm{C}\right)$ cupferron wash solution. Transfer the paper and precipitate to a $25-\mathrm{ml}$ porcelain crucible, and ignite at a low temperature until the carbon has burned. Fuse the ignited oxides in 1 to $2 \mathrm{~g}$ of potassium pyrosulfate, transfer the crucible to a $250-\mathrm{ml}$ beaker, and dissolve the melt with
$30 \mathrm{ml}$ of diluted hydrochloric acid $(1+9)$.

Remove the crucible, and wash with warm water.

Add sodium hydroxide solution until the solution is neutral to litmus paper, then add an excess of $5 \mathrm{ml}$ and heat to boiling. Boil for $5 \mathrm{~min}$, add a small amount of paper pulp, and filter the warm solution through a close-texture paper containing pulp. Transfer the precipitate to the paper, and wash 12 to 15 times with ammonium nitrate (20 $\mathrm{g}$ /liter) wash solution. Transfer the paper and precipitate to a porcelain crucible, and ignite at a low temperature. Fuse the ignited oxides in $1 \mathrm{~g}$ of potassium pyrosulfate, dissolve the melt in $30 \mathrm{ml}$ of diluted sulfuric acid $(1+9)$, and add a little paper pulp. Filter the solution through a close-texture paper containing paper pulp, catching the filtrate in a $100-\mathrm{ml}$ volumetric flask. Wash 8 to 10 times, and dilute to volume, with diluted sulfuric acid $(1+9)$. If necessary, transfer a suitable aliquot containing not more than $2.5 \mathrm{mg}$ of titanium to a $100-\mathrm{ml}$ volumetric flask and dilute to the mark with diluted sulfuric acid $(1+9)$. Since the solutions are to be combined for the determination of zirconium, all aliquoting, cell rinsing, etc., should be carried out in such a way as to achieve this objective.

For the photometric determination of titanium, rinse a photometer cell 3 times with 3 to $4 \mathrm{ml}$ of the solution from the $100-\mathrm{ml}$ volumetric flask, transferring the rinsings to a $400-\mathrm{ml}$ beaker. Transfer $15 \mathrm{ml}$ of the solution to a 2 -cm photometer cell for use as a reference solution. Add $1.0 \mathrm{ml}$ of hydrogen peroxide $(30 \%)$ to the solution remaining in the flask and mix thoroughly. Transfer a suitable portion to the matched 2-cm photometer cell for use as the sample solution. Using the reference solution, adjust the photometer to the initial setting using a narrow light band centered at approximately $410 \mathrm{~m} \mu$. While maintaining this photometer adjustment, take the photometric reading of the sample solution.

Transfer the solutions to the $400-\mathrm{ml}$ beaker, and reserve for the determination of zirconium. Determine the amount of titanium from a calibration curve prepared as follows: Transfer 0.0, 2.0, 5.0, and 10.0 $\mathrm{ml}$ of standard titanium solution to each of four 100$\mathrm{ml}$ volumetric flasks, and dilute to volume with diluted sulfuric acid $(1+9)$. Continue as described in the preceding paragraph, and plot the photometric readings of the calibration solutions with respect to milligrams of titanium, or calculate a factor [8]. The solutions obey Beer's Law and blanks are usually negligible. Since "difference" photometric measurements of this type are dependent for accuracy on an additive absorbancy function, a narrow-band filter photometer or spectrophotometer is desirable for the measurements.

In preparing the solution for the sodium hydroxide separation, a turbid solution is obtained if the sample contains appreciable tungsten. The sodium hydroxide separation removes most of the tungsten, along with the vanadium. In order to check for the complete removal of vanadium, photometric readings on the peroxide treated solution were made at approximately $515 \mathrm{~m} \mu$. A change in ratio of the absorbancy at $410 \mathrm{~m} \mu$ to that at $515 \mathrm{~m} \mu$ will indicate 
vanadium. Vanadium occlusion in the precipitate amounts to less than the equivalent of $0.1 \mathrm{mg}$ of titanium, even where as much as $50 \mathrm{mg}$ of vanadium is involved.

\section{b. Zirconium (+Hafnium)}

\section{Reagents}

Ammonium Phosphate Solution (300 g/liter). Dissolve $60 \mathrm{~g}$ of diammonium hydrogen phosphate in $150 \mathrm{ml}$ of water. Filter if necessary, and dilute to $200 \mathrm{ml}$ with water.

Ammonium Nitrate Wash Solution (50 g/liter). Dissolve $25 \mathrm{~g}$ of ammonium nitrate in $400 \mathrm{ml}$ of water, and dilute to $500 \mathrm{ml}$ with water.

\section{Procedure}

Transfer all of the sample solution and washings from the titanium determination to a $400-\mathrm{ml}$ beaker, and adjust to a volume of $200 \mathrm{ml}$ or less, with the acidity approximately 10 percent by volume in sulfuric acid. Add 1 to $2 \mathrm{ml}$ of hydrogen peroxide $(30 \%)$ and $25 \mathrm{ml}$ of ammonium phosphate solution, and allow to stand overnight at a temperature of $35^{\circ}$ to $40^{\circ} \mathrm{C}$. (with a milligram or less of zirconium, let the solution stand a day or two). Add $1 \mathrm{ml}$ of hydrogen peroxide, cool, add paper pulp, and filter through a close-texture paper containing a little pulp. Transfer the precipitate to the paper, and wash 18 to 20 times with ammonium-nitrate wash solution $(50 \mathrm{~g}$ /liter). Unfortunately, the zirconium phosphate precipitate tends to change composition, so the washing technique should be such as to leave the proper composition [10, p. 569, footnote 20]. Transfer the paper and precipitate to a weighed porcelain crucible, and ignite first at a low temperature to remove carbon, and finally ignite at $1,050^{\circ} \mathrm{C}$. for 20 min. Cool, and weigh as $\mathrm{ZrP}_{2} \mathrm{O}_{7}+\mathrm{HfP}_{2} \mathrm{O}_{7}$.

The precipitate also contains any hafnium in the alloy, since the acid mixture chosen for elution does not give an appreciable fractionation of titanium, zirconium, and hafnium. If suitable conditions can be established without too much extra manipulation, the use of mandelic acid $[9,17]$ as a precipitant is attractive, particularly for the larger amounts where the advantage of the phosphate conversion factor is more than outweighed by the lack of a definite composition. A good color reaction reasonably specific for zirconium is also needed for small quantities, where the normal hafnium ratio of 2 or 3 percent is not critical.

$$
\text { c. Niobium }
$$

Reagents

Zirconium Sulfate Solution (1 ml:-approximately $10 \mathrm{mg}$ of zirconium). Dissolve $3.90 \mathrm{~g}$ of zirconium sulfate tetrahydrate in $75 \mathrm{ml}$ of diluted sulfuric acid $(1+19)$, transfer to a $100-\mathrm{ml}$ volumetric flask, and dilute to volume with diluted sulfuric acid $(1+19)$. This solution must be low in titanium and iron, as well as niobium and tantalum. It was prepared from salt purified by the method of Clabaugh and Gilchrist [3].

Ammonium Oxalate Solution (40 g/liter). Dissolve
$40 \mathrm{~g}$ of ammonium oxalate in $900 \mathrm{ml}$ of warm water, filter if necessary, and dilute to $1,000 \mathrm{ml}$ with water.

Stannous Chloride Solution (200 g/liter). Dissolve $100 \mathrm{~g}$ of stannous chloride dihydrate in $400 \mathrm{ml}$ of diluted hydrochloric acid $(1+1)$ by heating on the steam bath. Cool and dilute to $500 \mathrm{ml}$ with diluted hydrochloric acid $(1+1)$.

Hydroquinone Solution (50 g/liter). Dissolve $20 \mathrm{~g}$ of hydroquinone in $400 \mathrm{ml}$ of sulfuric acid.

Standard Niobium Solution (1 $\mathrm{ml}=40 \mu \mathrm{g}$ of $n i$ obium). Transfer $0.0115 \mathrm{~g}$ of niobium pentoxide to a porcelain crucible. Add $1 \mathrm{~g}$ of potassium pyrosulfate, heat to fuse the niobium oxide, and dissolve the cooled melt with continuous stirring in $30 \mathrm{ml}$ of warm ammonium oxalate solution. Transfer the cooled solution to a 200-ml volumetric flask and dilute to volume with ammonium oxalate solution. This solution should be prepared as needed.

Procedure

To the third fraction (approximately $300 \mathrm{ml}$ ) containing the niobium, add $15 \mathrm{~g}$ of boric acid, 70 $\mathrm{ml}$ of hydrochloric acid, $80 \mathrm{ml}$ of water, and $2 \mathrm{ml}$ of zirconium sulfate solution. Warm on the steam bath $\left(30^{\circ}\right.$ to $\left.35^{\circ} \mathrm{C}\right)$ and stir occasionally to dissolve the boric acid. Cool to $5^{\circ} \mathrm{C}$, and add slowly while stirring, $30 \mathrm{ml}$ of cupferron solution. Add paper pulp, stir well to distribute the pulp and allow to stand 10 to $15 \mathrm{~min}$. Filter through a double thickness of $7-\mathrm{cm}$ close-texture paper fitted to a Büchner funnel. Transfer the precipitate to the filter, and wash well using $400 \mathrm{ml}$ of cold cupferron wash solution. Transfer the paper and precipitate to a porcelain crucible and ignite at a low temperature $\left(500^{\circ}\right.$ to $550^{\circ} \mathrm{C}$ ). Add $1 \mathrm{~g}$ of potassium pyrosulfate to the crucible, and fuse to dissolve the mixed oxides. Transfer the crucible and melt to a $100-\mathrm{ml}$ beaker and dissolve the melt in $25 \mathrm{ml}$ of warm ammonium oxalate solution. The fusion should be agitated with a stirring rod while dissolving, in order to prevent a localized high concentration of niobium which might lead to the precipitation of the hydrous oxide. Transfer the solution to a 100 - or $200-\mathrm{mI}$ volumetric flask, and dilute to volume with ammonium oxalate solution. Transfer a suitable aliquot containing not more than $0.3 \mathrm{mg}$ of niobium to a weighed $100-\mathrm{ml}$ beaker.

Add $10 \mathrm{ml}$ of diluted sulfuric acid $(1+1), 5 \mathrm{ml}$ of nitric acid, and 3 to $5 \mathrm{ml}$ of hydrochloric acid. Heat on a hot plate until moderate fumes of sulfuric acid are evolved, cool, and wash down the sides of the beaker with water. Cool, add 2 or 3 drops of hydrogen peroxide $(30 \%)$, and again heat to moderate fumes of sulfuric acid. Repeat the washing and hydrogen peroxide addition, and again evaporate to fumes. Finally, wash down the sides of the beaker, and heat to moderate fumes of sulfuric acid. Cool, add 1 drop of stannous chloride solution, and mix well by swirling the beaker. Add hydroquinone solution to make $100 \mathrm{~g}$ of solution in the beaker, and mix the solution thoroughly. Transfer a suitable portion of hydroquinone solution to a $2-\mathrm{cm}$ photometer cell for use as a reference solution. Transfer a portion of the test solution prepared above to a 
matched 2-cm photometer cell for use as the sample solution. Using the reference solution, adjust the photometer to the initial setting using a light band centered at $490 \mathrm{~m} \mu$. While maintaining this photometer adjustment, take the photometric reading of the sample solution.

Determine the amount of niobium present in the test solution from a calibration curve prepared as follows: Transfer $0.0,2.0,5.0$, and $10.0 \mathrm{ml}$ of standard niobium solution $(40 \mu \mathrm{g} / \mathrm{ml})$ to four weighed $100-\mathrm{ml}$ beakers, and continue as directed in the preceding paragraph. Plot the photometric readings of the calibration solutions with respect to micrograms of niobium. The hydroquinone photometric method has an appreciable temperature coefficient (approximately 0.6 to $0.7 \% / \mathrm{deg}$ ), so that the photometric readings must be carried out at a controlled temperature, or a separate set of calibration solutions must be carried along with each set of determinations. Since it was not convenient to control the temperature, the latter alternative was used for the determinations reported in this paper. The photometric measurements on these solutions follow Beer's Law, and blanks are usually negligible. The wavelength selected for the measurements is on the long wavelength side of the peak absorbancy primarily to extend the concentration range, and because somewhat better precision was obtained.

It is more convenient to determine niobium in a suitable aliquot by developing a color with hydrogen peroxide [21] in a sulfuric-phosphoric acid medium, but the zirconium used as a gatherer interferes in this procedure. Attempts to use tin as a gatherer were not successful because the ignited oxides do not fuse readily in pyrosulfate. If $20 \mathrm{mg}$ or more of niobium is involved, the determination can be conveniently completed by precipitation with cupferron as described in the first paragraph of this procedure. The addition of zirconium sulfate solution is of course omitted, and the oxide ignited at $1,000^{\circ} \mathrm{C}$ and weighed as niobium pentoxide. Losses due to incomplete precipitation or solubility do not exceed $0.5 \mathrm{mg}$ of niobium.

\section{d. Tantalum}

\section{Reagents}

Ammonium Oxalate-Ammonium Citrate Solution. Add $25 \mathrm{ml}$ of sulfuric acid to $975 \mathrm{ml}$ of water, and mix well. Add $40 \mathrm{~g}$ of ammonium oxalate monohydrate and $50 \mathrm{~g}$ of diammonium citrate, and warm $\left(30^{\circ}\right.$ to $\left.35^{\circ} \mathrm{C}\right)$ on the steam bath to dissolve the salts. Filter through a dry filter, if necessary, to obtain a clear solution.

Pyrogallic Acid Solution (200 g/liter). Dissolve $100 \mathrm{~g}$ of pyrogallic acid in $400 \mathrm{ml}$ of ammonium oxalate-ammonium citrate solution, dilute to 500 $\mathrm{ml}$ with the same solution, and transfer to a glassstoppered bottle. This solution is not especially stable, and a fresh solution should be prepared if the blank photometric reading is excessive. Occasional lots of pyrogallic acid have been observed to give a solution which is excessively colored, even though freshly prepared.

Standard Tantalum Solution (1 ml $\approx=0.125 \mathrm{mg}$ tantalum). Transfer $0.0305 \mathrm{~g}$ of tantalum pentoxide to a porcelain crucible. Add $1 \mathrm{~g}$ of potassium pyrosulfate to the crucible, heat to fuse the oxide, and dissolve the cooled melt with continuous stirring in $75 \mathrm{ml}$ of warm ammonium oxalate-ammonium citrate solution. Transfer the cooled solution to a $200-\mathrm{ml}$ volumetric flask and dilute to volume with ammonium oxalate-ammonium citrate solution. This solution should be prepared as needed.

\section{Procedure}

To the fourth fraction (approximately $270 \mathrm{ml}$ ), containing the tantalum, add $8 \mathrm{~g}$ of boric acid, 75 $\mathrm{ml}$ of hydrochloric acid, $80 \mathrm{ml}$ of water, and $2 \mathrm{ml}$ of zirconium sulfate solution. Warm on the steam bath $\left(30^{\circ}\right.$ to $\left.35^{\circ} \mathrm{C}\right)$ and stir occasionally to dissolve the boric acid. Cool to $5^{\circ} \mathrm{C}$ and add slowly, with continuous stirring, $25 \mathrm{ml}$ of cupferron solution. Add paper pulp, stir well to distribute the pulp and allow the solution to stand 10 to 15 min. Filter through a double thickness of 7-cm close-texture paper fitted to a Büchner funnel. Transfer the precipitate to the filter, and wash well with $400 \mathrm{ml}$ of cupferron wash solution. Transfer the paper and precipitate to a porcelain crucible, and ignite at a low temperature $\left(500^{\circ}\right.$ to $\left.550^{\circ} \mathrm{C}\right)$. Add $1 \mathrm{~g}$ of potassium pyrosulfate to the crucible, and fuse to dissolve the mixed oxides. Transfer the crucible and melt to a $100-\mathrm{ml}$ beaker, and dissolve the melt in 25 to $50 \mathrm{ml}$ of warm ammonium oxalateammonium citrate solution. The fusion should be agitated with a stirring rod while dissolving, in order to prevent a localized high concentration of tantalum which might lead to the precipitation of the hydrous oxide. Transfer the solution to a 50- or $100-\mathrm{ml}$ volumetric flask and dilute to volume with ammonium oxalate-ammonium citrate solution. Transfer with a pipet $25 \mathrm{ml}$ of pyrogallic acid solution to a $50-\mathrm{ml}$ volumetric flask. Transfer a suitable aliquot, not to exceed $25 \mathrm{ml}$ and containing not more than $1 \mathrm{mg}$ of tantalum, to the flask, and mix well.

Dilute to volume with the ammonium oxalateammonium citrate solution, mix thoroughly, and allow to stand $10 \mathrm{~min}$. Place water in a $2-\mathrm{cm}$ photometer cell for use as a reference solution. Transfer a portion of the test solution, prepared as above, to a matched $2-\mathrm{cm}$ photometer cell. Using the reference solution, adjust the photometer to the initial setting using a light band centered at 400 $\mathrm{m} \mu$. While maintaining this photometer adjustment, take the photometric reading of the test solution.

Determine the amount of tantalum present in the test solution from a calibration curve prepared as follows: Transfer with a pipet $25 \mathrm{ml}$ of pyrogallic acid solution to each of four $50-\mathrm{ml}$ volumetric flasks. Transfer $0.0,2.0,5.0$, and $10.0 \mathrm{ml}$ of standard tantalum solution $(125 \mathrm{\mu g} / \mathrm{ml})$ to the $50-\mathrm{ml}$ volumetric flasks, and continue as directed in the previous paragraph. Plot the photometric readings of the calibration solutions with respect to micrograms of tantalum. The solutions follow Beer's Law, but a blank is required to correct for the color contributed by the pyrogallic acid solution. Because of the variable quality of this reagent, the system 
of photometric readings is designed to allow poorquality lots to be detected and discarded. The reaction has a negligible temperature coefficient, but is sensitive to changes in pyrogallic acid concentration under the conditions specified in the procedure.

If $20 \mathrm{mg}$ or more of tantalum is involved, the determination can be conveniently completed by precipitation with cupferron as described in the first paragraph in this procedure. No zirconium addition is made, and the oxide is ignited at $1,000^{\circ} \mathrm{C}$ and weighed as tantalum pentoxide. Losses due to incomplete precipitation or solubility do not exceed $0.5 \mathrm{mg}$ of tantalum.

\section{Results}

Gram portions of high-purity niobium and tantalum pentoxides were prepared from commercial oxides by column elution with hydrochloric-hydrofluoric acid mixtures, precipitation with cupferron and ignition. Spectrographic examination of the niobium pentoxide indicated the chief impurities were boron and silicon. A chemical test made by ignition, treatment with sulfuric and hydrofluoric acids, and ignition, indicated these impurities to be negligible when using the oxide to prepare synthetic mixtures. Small amounts of silver, copper, calcium, iron, magnesium and tin were detected spectrographically and estimated to be less than 0.01 percent. A similar examination of the tantalum pentoxide indicated the same impurities, and in addition a very small amount of aluminum. It is likely that at least a part of the impurities that would ordinarily be removed by column separation actually represent contamination from dust distributed by the central air-heating system, resulting from plastering and painting work done at various times in the building while this project was in progress.

The results obtained on a series of synthetic mixtures made to simulate combinations of interest are given in table 1. Titanium and zirconium were added to the solution of the sample as aliquots of standard sulfate solutions prepared from National Bureau of Standards titanium dioxide Standard Sample 154a and from the zirconium sulfate referred to in section 3.3.c. Since stable solutions of niobium and tantalum cannot be prepared except through the use of complexing agents, weighed portions of the oxides were added to the first ignited cupferron concentrate. This mode of operation is justifiable on the basis that an appreciable part of these elements exists in steel as relatively insoluble carbides and nitrides which in any case cannot be duplicated by synthetic solution mixtures. A proof of the concentration step for these two elements would require more sensitive methods; possibly the use of active tracers in preparing the steels or activation analysis of the filtrate would define the lower limit. Since satisfactory replication was obtained on steels containing as little as $10 \mathrm{ppm}$ of either element, the limit to be established is quite low.

The values for titanium and tantalum shown in table 1 require little comment, the values being within the limits usually obtained from photometric determinations. The values for zirconium are slightly high, and illustrate the difficulties encountered in properly washing the zirconium phosphate precipitate [10, p. 569, footnote 20]. A gravimetric finish for this determination is preferred, as an ignited precipitate is available to examine spectrographically for hafnium. The values obtained on the larger quantities of niobium are slightly low, due to the loss of a few tenths of a milligram of niobium in the precipitation with cupferron from the eluate complexed with boric acid (section 3.3.c). Provisional certificate values for NBS Standard Sample 123b are: Niobium, 0.75 percent; tantalum, 0.20 percent; and titanium, 0.006 percent. These values are given to show that small additions of titanium and zirconium can be recovered satisfactorily from a stainless steel (type 347) matrix containing tungsten, molybdenum, niobium, and tantalum.

The method was designed to provide values for titanium, zirconium, niobium, and tantalum in the range of 0.001 to 0.5 percent, in the standardization of a group of spectrographic steel standards containing additions of 22 elements and the rare earths. A part of these data, as well as a few results obtained on three current NBS Standard Samples of steel, is shown in table 2 . In general, these values show

TABLE 1. Values obtained by the recommended procedure for titanium, zirconium, niobium, and tantalum on synthetic mixtures

\begin{tabular}{|c|c|c|c|c|c|c|c|c|c|}
\hline \multirow{2}{*}{ Samplea number } & \multirow{2}{*}{$\begin{array}{l}\text { Weight of } \\
\text { sample }\end{array}$} & \multicolumn{2}{|c|}{ Titanium } & \multicolumn{2}{|c|}{ Zirconium } & \multicolumn{2}{|c|}{ Niobium } & \multicolumn{2}{|c|}{ Tantalum } \\
\hline & & Added & Found & Added & Found & Added & Found & Added & Found \\
\hline $\begin{array}{l}55 \mathrm{~d} \\
55 \mathrm{~d} \\
55 \mathrm{~d} \\
55 \mathrm{~d} \\
55 \mathrm{~d} d \\
123 \mathrm{~b} \\
123 \mathrm{~b} \\
123 \mathrm{~b}\end{array}$ & $\begin{array}{c}g \\
5 \\
5 \\
5 \\
5 \\
5 \\
25 \\
25 \\
10 \\
10 \\
10 \\
10\end{array}$ & $\begin{array}{c}m g \\
10.3 \\
1.25 \\
25.0 \\
29.8 \\
0.60 \\
.60 \\
.25 \\
1.25\end{array}$ & $\begin{array}{c}m g \\
10.3 \\
1.27 \\
25.3 \\
29.4 \\
0.60 \\
.61 \\
.26 \\
.54 \\
.55 \\
1.78 \\
0.54\end{array}$ & $\begin{array}{c}m g \\
10.6 \\
26.4 \\
1.06 \\
0.52 \\
26.2 \\
0.52 \\
.53 \\
1.00 \\
0.5 \mathrm{C}\end{array}$ & $\begin{array}{c}m g \\
10.8 \\
26.7 \\
1.18 \\
0.64 \\
27.6 \\
0.53 \\
.57 \\
.05 \\
.00 \\
1.01 \\
0.57\end{array}$ & $\begin{array}{c}m g \\
10.7 \\
25.2 \\
0.60 \\
26.3 \\
0.30 \\
25.8 \\
0.30 \\
\\
\end{array}$ & $\begin{array}{c}m g \\
10.2 \\
\text { b } 24.9 \\
0.60 \\
\text { b } 26.1 \\
0.30 \\
25.4 \\
0.31 \\
\text { b } 74.6 \\
75.1 \\
\text { (c) } \\
\text { b } 74.3\end{array}$ & $\begin{array}{c}m g \\
16.7 \\
0.50 \\
24.9 \\
0.25 \\
24.4 \\
25.1 \\
0.25 \\
\end{array}$ & $\begin{array}{c}m g \\
10.7 \\
0.51 \\
\text { b } 24.9 \\
0.28 \\
\text { b } 24.3 \\
25.3 \\
0.27 \\
19.7 \\
19.9 \\
\text { (c) } \\
\text { b } 19.5\end{array}$ \\
\hline
\end{tabular}

a NBS Standard Sample.

b Determination finished gravimetrically.

c Not determined. 
TABLE 2. Values obtained by the recommended procedure for titanium, zirconium, niobium, and tantalum in NBS Standard Samples of steel

\begin{tabular}{|c|c|c|c|c|c|c|c|c|c|c|}
\hline \multirow{2}{*}{ Sample number } & \multirow{2}{*}{$\begin{array}{l}\text { Sample } \\
\text { weight }\end{array}$} & \multicolumn{2}{|c|}{ Titanium } & \multicolumn{2}{|c|}{ Zirconium (+Hf) } & \multicolumn{2}{|c|}{ Niobium } & \multicolumn{2}{|c|}{ Tantalum } & \multirow{2}{*}{ Type of steel } \\
\hline & & $\begin{array}{c}\text { Certificate } \\
\text { value }\end{array}$ & Found & $\begin{array}{c}\text { Certificate } \\
\text { value }\end{array}$ & Found & $\begin{array}{c}\text { Certificate } \\
\text { value }\end{array}$ & Found & $\begin{array}{c}\text { Certificate } \\
\text { value }\end{array}$ & Found & \\
\hline $101 d \ldots$ & $\stackrel{g}{25}$ & $\begin{array}{l}\% \\
(\mathrm{a})\end{array}$ & $\begin{array}{c}\% \\
0.0076\end{array}$ & $\begin{array}{l}\% \\
\text { (a) }\end{array}$ & $\begin{array}{c}\% \\
<0.005\end{array}$ & $\begin{array}{l}\% \\
(\mathrm{a})\end{array}$ & $\begin{array}{c}\% \\
0.003\end{array}$ & $\begin{array}{l}\% \\
\text { (a) }\end{array}$ & $\begin{array}{l}\% \\
<0.001\end{array}$ & $18 \mathrm{Cr}-9 \mathrm{Ni}$ \\
\hline $170 \mathrm{a} \ldots$ & 10 & b 0.28 & .271 & & $\begin{array}{r}<.005 \\
.036\end{array}$ & (a) & $\begin{array}{r}.003 \\
<.001\end{array}$ & (a) & $\sum .001$ & Open-hearth steel \\
\hline $121 \mathrm{c}_{\ldots}$. & 10 & b. 42 & $\begin{array}{l}.271 \\
.410 \\
.412 \\
038\end{array}$ & (a) & $\begin{array}{r}<.005 \\
<.005 \\
<.065\end{array}$ & (a) & $\begin{array}{r}<.001 \\
.003 \\
.003 \\
095\end{array}$ & (a) & $\sum .001$ & $18 \mathrm{Cr}-11 \mathrm{Ni}$ \\
\hline 462 and 1162 & 15 & .037 & $\begin{array}{l}.037 \\
.037 \\
010\end{array}$ & 0.063 & $\begin{array}{l}.061 \\
.064 \\
208\end{array}$ & 0.096 & $\begin{array}{l}.098 \\
.093 \\
192\end{array}$ & 0.036 & .036 & Low-alloy steel \\
\hline 463 and 1163 & 10 & .010 & $\begin{array}{l}.011 \\
.012\end{array}$ & (c) & $\begin{array}{l}.195 \\
.197\end{array}$ & .195 & $\begin{array}{l}.199 \\
.194\end{array}$ & .15 & $\begin{array}{l}.157 \\
.152\end{array}$ & Low-alloy steel \\
\hline 465 and $1165 \ldots$ & 25 & .20 & $\begin{array}{l}.207 \\
.206 \\
208\end{array}$ & (d) & $\begin{array}{l}.001_{4} \\
.000_{2}\end{array}$ & (e) & $\begin{array}{l}.001_{2} \\
.001_{4}\end{array}$ & .001 & $\begin{array}{l}.001_{2} \\
.001_{0}\end{array}$ & Low-alloy steel \\
\hline & & & $\begin{array}{l}.208 \\
.260\end{array}$ & & .094 & & $\begin{array}{l}.0011_{3} \\
.286\end{array}$ & & $\begin{array}{l}.0011_{0} \\
.230\end{array}$ & \\
\hline 467 and $1167 \ldots$ & 10 & .26 & $\begin{array}{l}.264 \\
.264\end{array}$ & 0.094 & $\begin{array}{l}.092 \\
.096\end{array}$ & 0.29 & $\begin{array}{l}.290 \\
.287\end{array}$ & .23 & $\begin{array}{l}.231 \\
.225\end{array}$ & Low-alloy steel \\
\hline A ....... & 10 & (i) & $\begin{array}{l}.056 \\
.055 \\
.056 \\
.056\end{array}$ & (f) & $\begin{array}{l}<.01 \\
<.01 \\
<.01 \\
<.01\end{array}$ & (f) & $\begin{array}{l}.498 \\
.494 \\
.491 \\
.489\end{array}$ & (i) & $\begin{array}{l}.022 \\
.023 \\
.022 \\
.022\end{array}$ & $19-9 \mathrm{DL}$ \\
\hline
\end{tabular}

a Value not certified.

b Provisional value.

- Value not certified because of uncertainty of spectrographic homogeneity of the sample.

d Value not certified because of poor performance of recommended method below 0.01 percent.

- Value not certified because spectrographic method not sufficiently sensitive at present.

\& Preliminary segregation test samples of fortheoming standard.

satisfactory replication, except for zirconium in those materials containing less than 0.01 percent of zirconium.

A quite satisfactory correlation between the chemical values was also obtained in setting up spectrographic curves; the exceptions were zirconium in the range below 0.01 percent where the performance of the chemical method is poor, and niobium below 0.01 percent where the spectrographic method lacks sufficient sensitivity at present to be useful.

Sample "A" illustrates the application of the procedure to a high-temperature material containing appreciable percentages of molybdenum and tungsten. It has already been shown [6] that niobium, molybdenum, and tungsten can be separated by anion exchange in hydrochloric-hydrofluoric acid mixtures, and it is hoped to further investigate mixtures of these elements in high-temperature alloys.

\section{References}

[1] F. H. Burstall and A. F. Williams, Analyst g7, 983 (1952).

[2] M. J. Cabell and I. Milner, Anal. Chim. Acta. 13, 258 (1955).

[3] W. S. Clabaugh and R. Gilchrist, J. Am. Chem. Soc. 74, $2104(1952)$.

[4] T. R. Cunningham, Ind. Eng. Chem., Anal. Ed. 5, 305 (1933).

[5] T. R. Cunningham, Ind. Eng. Chem., Anal. Ed. 10, 233 (1938).
[6] J. L. Hague, E. D. Brown, and H. A. Bright, J. Research NBS 53, 261 (1954) RP2542.

[7] J. L. Hague, E. E. Maczkowske and H. A. Bright, J. Research NBS 53, 353 (1954) RP2552.

[8] J. L. Hague, ASTM Proc. 44, 714 (1944).

[9] R. B. Hahn, Anal. Chem. 21, 1579 (1949).

[10] W. H. Hillebrand, G. E. F. Lundell, H. A. Bright, and J. I. Hoffman, Appl. Inorg. Analysis 2d ed., p. 588 (J. Wiley and Sons, Inc., New York, N. Y., 1953).

[11] L. Ikenberry, J. L. Martin, and W. J. Boyer, Anal. Chem. 25, 1340 (1953)

[12] C. M. Johnson, Iron Age 15\%, No. 15, 66 (1946).

[13] Silve Kallmann (Ledoux and Co., Teaneck, N. J.) private communication.

[14] K. A. Kraus and G. E. Moore, J. Am. Chem. Soc. 73, 9 (1951).

[15] K. A. Kraus and G. E. Moore, J. Am. Chem. Soc. 73, 2900 (1951)

[16] K. A. Kraus and F. Nelson, Proc. Intern. Conf. Peaceful Uses Atomic Energy \%, p. 116 (United Nations, N. Y., 1956).

[17] C. A. Kumins, Ind. Eng. Chem., Anal. Ed. 19, 376 (1947).

[18] L. A. Machlan and J. L. Hague, J. Research NBS 59, 415 (1957) RP2812.

[19] W. R. Schoeller, Analytical chemistry of tantalum and niobium, p. 1 (Chapman and Hall, Ltd., London, 1937).

[20] W. R. Schoeller and A. R. Powell, The analysis of minerals and ores of the rarer elements, 3d. ed., p. 210 (Hafner Publishing Co., New York, N. Y., 1955).

[21] G. Telep and D. F. Boltz, Anal. Chem. 24, 163 (1952).

Washington, July 14, 1958. 